\title{
An Exploratory Study Of Factors Influencing Organisational Justice Among Government Employees
}

\author{
Ophillia Ledimo, University of South Africa (UNISA), South Africa
}

\begin{abstract}
Organisational justice has become prominent within the leadership literature as an underlying and important aspect of governance. This study set out to examine factors influencing employees' organisational justice perceptions in a South African government department. The perceptions of the 289 participants were investigated by using the Organisational Justice Measurement Instrument (OJMI) as a measure of organisational justice. Descriptive statistics of the sample and factor analysis were conducted to analyse the data and to determine the factors that contributed to the perceptions of organisational justice of government employees. Results of the Cronbach alpha indicated that the OJMI is a reliable measuring instrument for the construct of organisational justice. The findings of this study identified the nine underlying factors that contributed to the perceptions of organisational justice as strategic direction, distributive, procedural, interactional, informational, service delivery and innovation, diversity management, customer relations, ethical leadership and management. This study suggests that to enhance the perceptions of organisational justice, leaders in government departments should focus on the identified nine factors. The implications of the findings are discussed and recommendations for future research are made.
\end{abstract}

Keywords: Organisational Justice; Leadership; Government; Injustice

\section{INTRODUCTION}

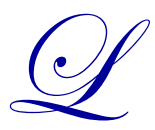

eaders in organisations are responsible for demonstrating the management of organisational justice through building fairness in the development and implementation of organisational policies, regulations and procedures governing all the managerial practices such as recruitment and selection, performance management, training and development, employee remuneration and benefits, employee wellness, labour relations and change management. Organisational justice is important to leaders because when justice is advocated as a core value of an organisation's management philosophy and enacted through a set of internally consistent management practices, it can build a culture of justice, a system-wide commitment that is valuable and unique in the eyes of the employees and customers, and may ultimately lead to a competitive advantage (van der Bank, Engelbrecht, and Strumpher, 2010).

Justice in an organisation defines the very essence of individuals' relationship with their employers and it is required in both corporate and government organisations. It is the employees' sense of moral propriety of how they are treated by their leaders or organisation, and it is the "glue" that allows employees to work together effectively (Cropanzano, Bowen and Gilliland, 2007).

Organisational justice as the just and ethical treatment of individuals within an organisation requires leaders and managers to implement fair practices within their organisation. However, the challenge faced by managers and leaders in government is being able to determine the organisational factors that influence justice. When leaders and managers have insight of the factors that are relevant to justice in organisations they will be able to enhance or improve their employees' perceptions of justice. As a result the organisation is able to eliminate labour disputes resulting from employees' perceptions of organisational injustice in its policies and practices. It is therefore 
necessary to empirically examine the factors that determine employees' perceptions of organisational justice among government employees, with a view to promoting positive labour relations between government and its employees. Hence this study was aimed at exploring this pertinent issue in a South African government department.

\section{LITERATURE REVIEW}

The following literature review focuses on the definition of organisational justice, its value in organisations, and factors that influence justice.

\section{Definition of Organisational Justice}

According to Greenberg (1987), the construct of organisational justice refers to an employee's perception of their organisation's behaviours, decisions and actions, and how these influence the employees' own attitudes and behaviours at work. In other words, organisational justice is a personal evaluation of the ethical and moral standing of managerial conduct (van der Bank et al., 2010). According to Cropanzano et al. (2007), this definition of organisational justice is a descriptive approach, which seeks to understand why employees view certain events as just, as well as the consequences that follow from these evaluations. Hence, justice within the organisation is viewed as a subjective and descriptive concept because it captures what the individual employees believe to be right, rather than an objective reality or a prescriptive moral code.

\section{Value of Organisational Justice}

Organisational justice as the employees' perceptions of fairness in their employment relationship suggests that these perceptions influence employee behaviour and attitudes in a positive or negative manner (Colquit, Greenberg and Zapata-Phenan, 2005). Greenberg (2001) has argued that organisational justice attempts to describe and explain the role of fairness in the workplace. It has the potential to create positive implications for organisations and employees such as greater trust and commitment, improved job performance, more helpful citizenship behaviours, improved customer satisfaction, and diminished conflict (Cropanzano et al., 2007). Shibaoka, Takade, Watanabe, Kojima, Kakinuma, Tanaka, and Kawakami (2010) have pointed out that organisational justice has recently attracted attention as a predictor of employee mental and physical health. Organisations are seeking affordable and effective means to improve employees' psychological health and prevent costs related to mental health problems such as poor performance and absenteeism (Gaudet, Trambley and Doucet, 2014).

According to Cropanzano, Rupp, Mohler, and Schminke (2001), the following are the three reasons organisational justice is important to employees:

- $\quad$ Firstly, the long-range benefit. This implies that employees prefer justice because it allows them to predict and control the outcomes they are likely to experience in their organisations.

- Secondly, social consideration. Employees as social beings prefer to be accepted and valued by important others while not being exploited or harmed by powerful decision-makers in their organisations.

- Thirdly, ethical consideration. Employees are concerned about organisational justice because they believe it is the morally appropriate way to treat others.

In addition to the above, Colquit (2001) has indicated that organisational justice perceptions lead to employee commitment and trust. Cropanzano, Prehar and Chen (2002) have also indicated that justice improves employees' job performance in an organisation. Employees who perceive justice in their organisation are inclined to want to perform as a form of reciprocity (Gaudet et al., 2014). Justice affects what employees believe about the organisation as a whole because when the process is perceived as just, employees' show greater loyalty and more willingness to behave in an organisation's best interests; they are also less likely to betray the institution and its leaders (Cropanzano et al., 2007). Bowen, Gilliland and Folger (1999) have suggested that a just treatment of employees will lead to organisational citizenship behaviours that "spill over" to customers. In other words, organisational justice has a positive impact on employees' organisational citizenship behaviour, loyalty and customer satisfaction. 
In contrast to the positive influence of organisational justice on employee attitudes and behaviour, an injustice within an organisation is perceived as a corrosive solvent that can dissolve bonds within the organisation; hence injustice within the organisation is hurtful to employees and harmful to the organisation itself (Cropanzano et al., 2007). Van der Bank et al. (2010) have argued that the results of unfair treatment by employees may include emotions of anger and resentment, lower production quantity and quality, greater absenteeism, greater turnover, less initiative, lower morale, lack of cooperation, spread of dissatisfaction to co-workers, fewer suggestions and less selfconfidence. It is therefore, essential that organisations are able to identify and determine additional factors within the organisation that are likely to engender employees' subjective perception of organisational justice.

\section{Factors Related to Organisational Justice}

Following from the above discussion regarding the description and benefits of organisational justice, several research studies have been conducted to determine factors that influence justice in organisations. For instance, justice and fairness permeates many actions and reactions that occur in organisations because when a decision, procedure or interaction is seen as inappropriate employees will usually experience a fairness violation (Pilvinyte, 2013).

Moorman (1991) has argued that organisational justice factors are only procedural and interactional justice (a composite scale of interpersonal and informational justice). These factors excluded distributive justice or informational justice. In contrast, Colquitt (2001) highlighted the four factors that are related to organisational justice, namely procedural justice, distributive justice, interpersonal justice, and informational justice.

Distributive justice is the first fairness construct studied that focuses on perceptions of fairness of the distribution and allocation of outcomes (Pilvinyte, 2013). It focuses on the organisational reality that not all employees are treated alike, and that the allocation of outcomes is differentiated in the organisation (Cropanzano et al., 2007). Adams (1965) proposed that employees determine fairness by evaluating their perceived inputs relative to the outcomes they receive; then they compare this ratio to some referent standard to establish whether the outcomes are fair in relation to their inputs. Distributive justice refers to employees' perceptions of what constitutes a fair distribution of resources and it is assessed based on the rule of equity (Gaudet et al., 2014). Cropanzano et al. (2007) also distinguished the three allocation rules that can lead to distributive justice if they are applied appropriately, namely equality (to each the same), equity (to each in accordance with contributions), and need (to each in accordance with the most urgency). Gaudet et al. (2014) have explained that people implicitly calculate a ratio between contributions or performance offered and rewards received, and then compare this ratio with the situation of a reference person.

Procedural justice refers to the means by which outcomes are allocated, but not specifically to the outcomes (Cropanzano et al., 2007). It relates to the fairness of the formal procedures required by the organisation and its policy on the method of decision-making (Moorman, 1991; Colquitt, 2001). According to Gaudet et al. (2014), employees perceive procedural justice when the organisation enables them to participate in important decisions and when procedures leading to decisions are consistent, accurate, unbiased, correctable, ethical and representative of their concerns. Hence a just process is one that is applied consistently to all, free of bias, accurate, representative of relevant stakeholders, correctable and consistent with ethical norms (Cropanzano et al., 2007). This implies that a decision is fair if the outcomes are seen as balanced and correct, where balance refers to the fact that similar actions are taken in similar situations, and correctness refers to the fact that the quality is good (van der Bank et al., 2010). According to Cropanzanno et al. (2007), procedural justice establishes certain principles specifying and governing the roles of participants within the decision-making processes.

Interactional justice refers to the perceived fairness of the interpersonal treatment used to determine outcomes (Colquitt, 2001). It focuses on the sensitivity, politeness and respect employees receive from their superiors during procedures; this serves primarily to alter reactions to outcomes, because sensitivity can make people feel better even if the outcome is unfavourable (Pilvinyte, 2013). Sensitivity refers to how one person treats another in an organisation; because interactional justice emphasises one-on-one transaction, employees often seek it from their managers and leaders (Cropanzano et al., 2007). According to van der Bank et al. (2010), interactional justice refers to the thoroughness of the information provided as well as the amount of dignity and respect 
demonstrated when presenting an undesirable outcome. Cropanzano et al. (2007) have highlighted that an employee is interactionally just if he or she appropriately shares information and avoids rude or cruel remarks. In addition, interactional justice is the quality of the treatment received while procedures are applied in organisations (Gaudet et al., 2014).

Informational justice is described as to whether one is truthful and provides adequate justifications (Cropanzano et al. 2007). According to Pilvinyte (2013), it refers to the explanation, justification or information provided by decision-makers as to why outcomes were distributed in a certain way. This type of justice requires that the information should be comprehensive, reasonable, truthful, timely and candid.

While extensive research was conducted to confirm that the above four justice factors are related to organisational justice, there is room to explore other organisational factors that are relevant to measure this construct. This implies that organisational justice is not only limited to procedural justice, distributive justice, interpersonal justice, and informational justice. Firstly, one of the factors that need to be explored is the strategic planning or direction of the organisation. Kim and Mauborgne (1993) have argued that when employees believed that their leaders conducted a fair strategic planning process, they were more supportive of the plan, trusted their leaders more, and were more committed to their employers. Strategic direction is described and defined as the underlying purpose of the organisation, based on its vision and mission, business goals and objectives, operational plans as well as its organisational values (Mullins and Christy, 2013). Creating a justice-oriented strategic direction for the organisation is one of the means by which the organisation is able to indicate its concern for fair development and ethical execution of its purpose. Fair development of the strategic direction should focus on consultation with the relevant stakeholders during the decision-making process.

Secondly, justice is a significant virtue for leaders and managers as it prevents leaders from putting the organisation and employees at risk. Hence, ethical leadership and management is another factor that needs to be explored and studied because it refers to the conduct that is fair, protects the rights of others and is beneficial to all the stakeholders in the organisation. It is the responsibility of leaders and managers to ensure that they set aside their personal biases in order to make decisions regarding the organisation in an objective manner and reflecting respect for the rights of others in their roles (Johnson, 2009). Leaders and managers are responsible for influencing their subordinates' perceptions of justice in their practices (Gaudet et al., 2014).

Thirdly, service delivery and innovation justice is an important factor of organisational justice because it focuses on employee perceptions of fairness with regard to product and service development or changes, marketing of services, stakeholder engagement and turnaround time on service delivery. Service delivery refers to the actual delivery of a service and products to the customer or clients (Lovelock and Wright, 2002). It is therefore concerned with the where, when, and how a service product is delivered to the customer and whether this is fair or unfair in nature. According to Chen, Tsou and Huang (2009), innovation in service delivery orientation refers to an organisation's openness to new ideas and propensity to change through adopting new technologies, resources, skills and administrative systems. The process of service delivery innovation which includes the communication and implementation of organisational changes can be perceived as being unfair or fair by its employees or members. Yet, there is a lacuna in the literature to explain the role of service delivery innovation in employees' perceptions of fairness.

Fourthly, organisations in both the public and private sector exist to provide services to their clients and customers. Justice in customer relations is crucial because it focuses on employee perceptions of fairness towards clients and customers with regard to their relationship, satisfaction, complaints handling and care. Customer relations is about customer interaction and about learning about customers' needs and preferences in order to provide more appropriate products and services to customers in the future (King and Burgess, 2008). A lot of customer complaints and dissatisfaction are due to unfair practices in customer care and relations during service delivery. Injazz and Karen (2004) describe customer relations as a coherent and complete set of processes and technologies for managing relationships with current and potential customers in order to capture and retain customers. Hence customer relations form the core of an organisation's business because this leads to greater customer satisfaction, increases the number of customers and secures greater loyalty (Chalmet, 2006). An effective customer relations system should enable an organisation to gain greater insight into customer behaviour and preferences. An 
assessment of employees' perceptions of justice in customer relations can enable the organisation to improve the effectiveness and efficiency of the processes involved in customer relationships.

Lastly, diversity management is regarded as an important aspect of organisational justice. Currently, an increasing number of organisations are attempting to enhance inclusiveness of underrepresented individuals through proactive efforts of managing their diversity (Gilbert, Stead and Invancevich, 1999). According to Magoshi and Chang (2009), diversity management is regarded as a reflection of commitment philosophy because it fundamentally implies the organisation's commitment to the diverse composition of the workforce as well as its diverse needs. It is a complete organisational cultural change designed to foster appreciation of demographic, ethnic, and individual differences and to accomplish a cultural change designed to value diversity and involves modification of existing procedures and practices (Gilbert et al., 1999). Diversity management is important in organisations because of its positive effects, which are increased productivity, competitiveness, and workplace harmony (Ivancevich and Gilbert, 2000). Therefore diversity management is related to organisational justice because the eradication of bias and prejudice is one of the goals of diversity management programmes in organisations.

It is against the above background that this study aimed to explore the factors influencing employees' perceptions of organisational justice in a South African government department.

\section{RESEARCH DESIGN AND METHODOLOGY}

This section describes the research design, participants and sampling, measuring instrument and procedure as well as the statistical analysis of data.

\section{Research Design}

In order to achieve the objective of the empirical study, a quantitative design using a cross-sectional survey was adopted because it enabled the researcher to collect data from a large population (Wellman, Kruger and Mitchell, 2009).

\section{Participants}

The participants of this study were 289 employees of a South African government department. A simple random sampling approach was used in order to ensure that the sample would be representative of the population and unbiased (Terreblanche, Durrheim and Painter, 2006). In terms of the sample size for this study, the researcher used the parameter that 200 to 500 participants are adequate for multivariate statistical analysis such as factor analysis (Avikaran, 1994).

\section{Measuring Instrument and Procedure}

The questionnaire consisted of two sections. Section A measured the participants' biographical details, which included race, age, gender, tenure and job level. Section B consisted of the Organisational Justice Measurement Instrument (OJMI) which is a virtually self-administering survey and consists of 59 statements measuring the nine factors of justice as strategic direction, distributive, procedural, interactional, informational, service delivery and innovation, customer relations, diversity management, ethical leadership and management. The statements of the questionnaire were configured using a five-point Likert scale ranging from 1, strongly disagree, to 5 , strongly agree.

The ethical clearance to conduct the research in the organisation was granted by the management and the ethics committee of the department and research institution. An invitation to participate voluntarily in the study was sent to the employees. The questionnaire was completed during a group administration process facilitated by the researcher and it included a covering letter. The covering letter explained the purpose of the study and it explained ethical concerns such as anonymity, confidentiality, feedback and freedom of choice to participate in the study. The completed questionnaires were collected immediately by the researcher and were kept in a secure place. 


\section{Statistical Analysis of Data}

Descriptive and inferential statistics data analyses were conducted in this study using the Statistical Package for Social Sciences (SPSS, version 21.0). The descriptive statistics were used to analyse the biographic variables of the sample and the reliability of the questionnaire. Exploratory factor analysis as inferential statistics was used to identify the factors that determine organisational justice perceptions of government employees. In addition, the mean score ranking technique was conducted to compare the importance of the extracted factors relative to each other.

\section{RESULTS OF THE STUDY}

The findings of this study are presented firstly, focusing on the sample composition. Secondly, the reliability and descriptive statistics of the measuring instruments are discussed. Lastly, the inferential statistical analysis using the exploratory factor analysis, internal consistencies and mean scores of the factors are presented.

\section{Sample Composition}

Table 1 presents the profile of the participants in this study. In terms of gender, $59.5 \%(n=172)$ were female and $40.5 \%(n=117)$ were male. With regard to the different race groups of the participants, $78.9 \%(n=228)$ were African; 9.7\% $(\mathrm{n}=28)$ were white; $8 \%(\mathrm{n}=23)$ were coloured and $3.5 \%(\mathrm{n}=10)$ were Indian. Among the participants, approximately $22.1 \%(\mathrm{n}=64)$ were born between 1946 and $1964 ; 38.1 \%(\mathrm{n}=110)$ were born between 1965 and 1977 while $39.8 \%(\mathrm{n}=115)$ were born between 1978 and 2000. In terms of the participants' current position, $17 \%(\mathrm{n}=49)$ were in management positions; $46.3 \%(\mathrm{n}=134)$ occupied professional and specialist positions, while $36.7 \%(\mathrm{n}=106)$ were employed as general workers. In addition, $56.8 \%(\mathrm{n}=164)$ of the participants had been in the employ of the organisation from 1 to 5 years.

\begin{tabular}{lcc}
\multicolumn{3}{c}{ Table 1. Demographic profile of participants } \\
\hline Parameter & Frequency & Percentage (\%) \\
\hline Gender & 117 & \\
\hline Male & 172 & 50.5 \\
Female & & \\
\hline Race & 228 & 78.9 \\
\hline African & 23 & 8.0 \\
Coloured & 10 & 3.5 \\
Indian & 28 & 9.7 \\
White & & \\
\hline Age group & 115 & 39.8 \\
\hline Born between 1978 and 2000 & 110 & 38.1 \\
Born between 1965 and 1977 & 64 & 22.1 \\
Born between 1946 and 1964 & & \\
\hline Years of service & 164 & 56.8 \\
\hline 1 - 5 years & 63 & 21.8 \\
6-10 years & 41 & 14.2 \\
11- 15 years & 21 & 7.2 \\
Over 16 years & & \\
\hline Current position & 49 & 17 \\
\hline Management & 134 & 46.3 \\
Professional and specialist & 106 & 36.7 \\
\hline
\end{tabular}

\section{Validity and Reliability}

In terms of the content and face validity of the instrument, the researcher asked a panel of five experts in organisational behaviour and governance to review the survey items in order to determine whether the content was suitable for measuring the intended constructs. In addition, a pilot study was conducted with a convenience sample of 30 participants as a pre-test of the instrument. The feedback from the panel of experts and pilot study was used to 
make changes to the instrument items, which included rewording and rephrasing items as well as deleting and adding items. With regard to the construct validity, the reliabilities of the factors were used to assess the construct validity and it was measured using Cronbach's alpha co-efficient. The Cronbach's alpha coefficients for the nine organisational justice factors are presented in Table 2 below; the results of the coefficients are considered to be satisfactory because they were significantly greater than the recommended 0.70 (Terreblanche et al., 2006). They varied from 0.946 (distributive), 0.942 (ethical leadership and management), 0.909 (service delivery and innovation), 0.884 (strategic direction), 0.862 (interactional), 0.887 (informational), 0.863 (procedural), 0.815 (diversity management) to 0.799 (customer relations). The construct validity was also measured using the exploratory factor analysis (EFA); the results indicated that there were no cross-loadings within constructs of the nine organisational justice factors.

Table 2. Number of items, reliabilities, means and standard deviations for the organisational justice subscales

\begin{tabular}{lccccc}
\hline \multicolumn{1}{c}{ Factor } & $\begin{array}{c}\text { Number of } \\
\text { items }\end{array}$ & Reliability & Mean score & $\begin{array}{c}\text { Standard } \\
\text { deviation }\end{array}$ & $\begin{array}{c}\text { Position in } \\
\text { rank order }\end{array}$ \\
\hline Distributive justice & 12 & 0.946 & 3.31 & 0.978 & 9 \\
Ethical leadership and management & 11 & 0.942 & 3.39 & 0.935 & 8 \\
Service delivery and innovation & 6 & 0.909 & 3.58 & 0.836 & 5 \\
Strategic direction justice & 5 & 0.884 & 3.62 & 0.933 & 4 \\
Interactional justice & 5 & 0.862 & 3.83 & 0.862 & 1 \\
Informational Justice & 7 & 0.887 & 3.71 & 0.840 & 3 \\
Procedural justice & 5 & 0.863 & 3.41 & 0.929 & 7 \\
Diversity management justice & 4 & 0.815 & 3.54 & 0.946 & 6 \\
Customer relations justice & 4 & 0.799 & 3.73 & 0.824 & 2 \\
\hline
\end{tabular}

\section{Internal Consistencies and Mean Scores}

Table 2 above also presents the internal consistencies and mean scores of the scales used in this study. The summated means for the nine organisational justice subscales indicate that interactional justice was ranked highest $(\mathrm{m}=3.83)$; followed by customer relations $(\mathrm{m}=3.73)$; informational $(\mathrm{m}=3.71)$; strategic direction $(\mathrm{m}=3.62)$; service delivery and innovation $(\mathrm{m}=3.58)$; diversity management $(\mathrm{m}=3.54)$; procedural $(\mathrm{m}=3.41)$; ethical leadership and management $(\mathrm{m}=3.39)$ and distributive $(\mathrm{m}=3.31)$.

This ranking of the means score results indicates that the government employees perceive more justice and fairness in the dimension interactional that the other eight factors. However, the fact that the mean scores for all the nine subscales were between the "agree" and "strongly agree" ratings on the Likert scale reflect that the employees of the government department seem to have satisfactory or positive perceptions of organisational justice.

\section{Exploratory Factor Analysis}

According to Brown (2006), factor analysis is a statistical multivariate procedure of which the main purpose is to determine the number and nature of latent factors that account for the variation and co-variation among a set of observed variables. An exploratory factor analysis was conducted in this study using the Principal Components Analysis (CPA) method and Varimax rotation in order to identify organisational justice factors (Hair, Black, Babin, Anderson, Tatham and Black, 2010). By performing EFA, the underlying factor structure is identified and the number of factors that exist in a set of variables and the degree to which the variables are related to the factors is determined (Kahn, 2006).

To enhance the interpretation of the factor structure, scale purification was used in this study to eliminate low factor loadings, cross-loadings and low communalities (Brown, 2006). Based on Hair et al.'s (2010) recommendation, the minimum cut-off point of 0.50 was applied for the variable loadings. Bartlett's test of sphericity and the Kaiser-Meyer-Olkin (KMO) measure of sampling adequacy were conducted to determine whether the sample data were suitable for explanatory factor analysis (Tabachnik and Fidell, 2001; Johnson and Wichern, 2002). The Kaiser-Meyer-Olkin (KMO) measure of sampling adequacy was calculated at $0.950(>0.50)$ and Bartlett's test of sphericity supported by an approximately Chi-square of 14697.602 at 2080 degrees of freedom (df) $(\mathrm{Sig}=0.000)$. 
Table 3 presents the results of the rotated factor loading matrix indicating the percentage of variance explained by each factor, cumulative percentage of variance and Eigen value criterion used for assessment. As a result, a nine-component solution was developed as the items were logically associated with the underlying factors. An analysis of the responses of the government department employees led to the identification of nine organisational justice factors; namely, distributive, procedural, strategic direction, interactional, informational, service delivery and innovation, diversity management, customer relations, ethical leadership and management.

The nine factors accounted for approximately $63.6 \%$ of the variance, complying with Hair et al. 's (2010) recommendation that the cumulative percentage of variance extracted by the factors should be at least $60 \%$. The explained total variance of $63.6 \%$ indicates that $36.4 \%$ of the organisational justice perception of government employees is accounted for by extraneous variables that did not form part of this study. In addition, all the nine identified factors showed acceptable levels of internal consistency or reliabilities based on Terreblanche et al. (2006) who recommend levels above the 0.70 threshold.

Table 3: Rotated component matrix for organisational justice factors

\begin{tabular}{|c|c|c|c|c|c|c|}
\hline $\begin{array}{l}\text { Item } \\
\text { code }\end{array}$ & Factors and variable description & $\begin{array}{l}\text { Factor } \\
\text { loadings }\end{array}$ & $\begin{array}{l}\text { Eigen } \\
\text { value }\end{array}$ & $\begin{array}{l}\% \text { of variance } \\
\text { explained }\end{array}$ & \begin{tabular}{|c|} 
Cumulative \\
percentage of \\
variance \\
explained
\end{tabular} & $\begin{array}{l}\text { Reliability } \\
\text { (Cronbach's } \\
\text { alpha) }\end{array}$ \\
\hline \multicolumn{7}{|c|}{ Factor 1 Distributive justice } \\
\hline 16 & $\begin{array}{l}\text { The mission and vision statement of the } \\
\text { organisation is clearly communicated to } \\
\text { all employees. }\end{array}$ & .774 & \multirow{12}{*}{9.111} & \multirow{12}{*}{14.01} & \multirow{12}{*}{14.01} & \multirow{12}{*}{0.946} \\
\hline 17 & $\begin{array}{l}\text { Employees are encouraged to act } \\
\text { ethically during the implementation of } \\
\text { the organisational strategy. }\end{array}$ & .770 & & & & \\
\hline 18 & $\begin{array}{l}\text { Financial resources are distributed fairly } \\
\text { to the different business units/department } \\
\text { in my organisation. }\end{array}$ & .758 & & & & \\
\hline 19 & $\begin{array}{l}\text { Employees in my organisation have equal } \\
\text { access to company resources to do their } \\
\text { work such as office space, computers, } \\
\text { telephones and cars. }\end{array}$ & .756 & & & & \\
\hline 20 & $\begin{array}{l}\text { In my organisation bonuses are rewarded } \\
\text { to high performing employees } \\
\text { irrespective of their position, department } \\
\text { or job level. }\end{array}$ & .755 & & & & \\
\hline 21 & $\begin{array}{l}\text { Employees doing the same work get } \\
\text { similar rewards. }\end{array}$ & 692 & & & & \\
\hline 22 & $\begin{array}{l}\text { Managers and employees salaries are fair, } \\
\text { based on their jobs. }\end{array}$ & .688 & & & & \\
\hline 23 & $\begin{array}{l}\text { In my organisation all employees are } \\
\text { involved in the decision-making } \\
\text { processes that are relevant to their work. }\end{array}$ & .641 & & & & \\
\hline 24 & $\begin{array}{l}\text { Employees are consulted during the } \\
\text { development of organisational policies } \\
\text { and procedures. }\end{array}$ & .589 & & & & \\
\hline 25 & $\begin{array}{l}\text { The performance management policy is } \\
\text { applied consistently to all employees. }\end{array}$ & .587 & & & & \\
\hline 26 & $\begin{array}{l}\text { Employees are promoted fairly based on } \\
\text { their skills and abilities. }\end{array}$ & .572 & & & & \\
\hline 27 & $\begin{array}{l}\text { In our organisation, the recruitment and } \\
\text { selection process is fair for all applicants. }\end{array}$ & .557 & & & & \\
\hline
\end{tabular}


(Table 3 continued)

\begin{tabular}{|c|c|c|c|c|c|c|}
\hline $\begin{array}{l}\text { Item } \\
\text { code }\end{array}$ & Factors and variable description & $\begin{array}{l}\text { Factor } \\
\text { loadings }\end{array}$ & $\begin{array}{l}\text { Eigen } \\
\text { value }\end{array}$ & $\begin{array}{l}\% \text { of variance } \\
\text { explained }\end{array}$ & \begin{tabular}{|c|} 
Cumulative \\
percentage of \\
variance \\
explained
\end{tabular} & $\begin{array}{l}\text { Reliability } \\
\text { (Cronbach's } \\
\text { alpha) }\end{array}$ \\
\hline \multicolumn{7}{|c|}{ Factor 2 Ethical leadership and management } \\
\hline 34 & $\begin{array}{l}\text { Employees are consulted before changes } \\
\text { are implemented in my organisation. }\end{array}$ & .753 & \multirow{11}{*}{6.800} & \multirow{11}{*}{7.223} & \multirow{11}{*}{24.47} & \multirow{11}{*}{0.946} \\
\hline 51 & My leaders are able to act morally. & .753 & & & & \\
\hline 52 & $\begin{array}{l}\text { Leaders in my organisation are able to } \\
\text { exert moral influence. }\end{array}$ & .719 & & & & \\
\hline 53 & $\begin{array}{l}\text { My leaders take responsibility for their } \\
\text { mistakes. }\end{array}$ & .652 & & & & \\
\hline 54 & $\begin{array}{l}\text { My leaders are able to put aside their } \\
\text { personal concerns to make objective } \\
\text { decisions. }\end{array}$ & 610 & & & & \\
\hline 55 & $\begin{array}{l}\text { My manager treats all employees } \\
\text { equally. }\end{array}$ & .590 & & & & \\
\hline 56 & $\begin{array}{l}\text { My manager uses the performance } \\
\text { evaluation discussion fairly to deal with } \\
\text { performance issues. }\end{array}$ & .584 & & & & \\
\hline 57 & $\begin{array}{l}\text { My manager adheres to organisational } \\
\text { policies and procedures. }\end{array}$ & .548 & & & & \\
\hline 58 & $\begin{array}{l}\text { My manager is able to resolves conflict } \\
\text { among employees in a fair manner. }\end{array}$ & .519 & & & & \\
\hline 59 & $\begin{array}{l}\text { My leaders are actively involved in } \\
\text { creating a fair working environment. }\end{array}$ & .503 & & & & \\
\hline 60 & $\begin{array}{l}\text { My manager supports fair practices in } \\
\text { the department unconditionally. }\end{array}$ & .501 & & & & \\
\hline \multicolumn{7}{|c|}{ Factor 3 Service delivery and innovation } \\
\hline 69 & $\begin{array}{l}\text { In my organisation the information } \\
\text { provided to employees on service } \\
\text { delivery and innovation changes is clear } \\
\text { and consistent. }\end{array}$ & .757 & \multirow{6}{*}{4.695} & \multirow{6}{*}{10.46} & \multirow{6}{*}{31.70} & \multirow{6}{*}{0.942} \\
\hline 70 & $\begin{array}{l}\text { I think we are sufficiently informed on } \\
\text { the progress of service delivery and } \\
\text { innovation changes. }\end{array}$ & .731 & & & & \\
\hline 71 & $\begin{array}{l}\text { In my organisation, the departments are } \\
\text { consulted about the reasons for service } \\
\text { delivery and innovation changes. }\end{array}$ & .717 & & & & \\
\hline 72 & $\begin{array}{l}\text { My manager treats customers/clients as } \\
\text { more important than things. }\end{array}$ & .655 & & & & \\
\hline 73 & $\begin{array}{l}\text { In my department we always follow } \\
\text { customer/client service policies and } \\
\text { practices. }\end{array}$ & .637 & & & & \\
\hline 74 & $\begin{array}{l}\text { My organistion uses competent } \\
\text { employees to render services and } \\
\text { products to clients/customers. }\end{array}$ & .559 & & & & \\
\hline \multicolumn{7}{|c|}{ Factor 4 Strategic direction justice } \\
\hline 10 & $\begin{array}{l}\text { Our organisational values show concern } \\
\text { for others' rights. }\end{array}$ & .728 & \multirow{5}{*}{4.279} & \multirow{5}{*}{6.584} & \multirow{5}{*}{38.28} & \multirow{5}{*}{0.909} \\
\hline 11 & $\begin{array}{l}\text { Our organisational values encourage all } \\
\text { employees to act with integrity in their } \\
\text { role. }\end{array}$ & .707 & & & & \\
\hline 12 & $\begin{array}{l}\text { Our organisational values encourage us } \\
\text { to take responsibility for our actions. }\end{array}$ & .681 & & & & \\
\hline 13 & $\begin{array}{l}\text { The values of the organisation encourage } \\
\text { employees to do the right thing no matter } \\
\text { what the consequences. }\end{array}$ & .657 & & & & \\
\hline 14 & $\begin{array}{l}\text { The organisation gives employees } \\
\text { adequate resources to achieve } \\
\text { organisational goals and objectives. }\end{array}$ & .644 & & & & \\
\hline
\end{tabular}


(Table 3 continued)

\begin{tabular}{|c|c|c|c|c|c|c|}
\hline $\begin{array}{l}\text { Item } \\
\text { code }\end{array}$ & Factors and variable description & $\begin{array}{l}\text { Factor } \\
\text { loadings }\end{array}$ & $\begin{array}{l}\text { Eigen } \\
\text { value }\end{array}$ & $\begin{array}{c}\% \text { of } \\
\text { variance } \\
\text { explained }\end{array}$ & $\begin{array}{l}\text { Cumulative } \\
\text { percentage } \\
\text { of variance } \\
\text { explained }\end{array}$ & $\begin{array}{l}\text { Reliability } \\
\text { (Cronbach' } \\
\text { s alpha) }\end{array}$ \\
\hline \multicolumn{7}{|c|}{ Factor 5 Interactional justice } \\
\hline 64 & $\begin{array}{l}\text { There is a strong collaboration between } \\
\text { colleagues in my department. }\end{array}$ & .777 & \multirow{5}{*}{4.244} & \multirow{5}{*}{6.530} & \multirow{5}{*}{44.81} & \multirow{5}{*}{0.884} \\
\hline 65 & $\begin{array}{l}\text { I have confidence in my colleagues } \\
\text { relating to each other in a fair manner. }\end{array}$ & .743 & & & & \\
\hline 66 & $\begin{array}{l}\text { My department is fair and honest in its } \\
\text { relationship with other departments in } \\
\text { the organisation. }\end{array}$ & .722 & & & & \\
\hline 67 & $\begin{array}{l}\text { My colleagues see me as someone who } \\
\text { relates fairly to them. }\end{array}$ & .722 & & & & \\
\hline 68 & $\begin{array}{l}\text { I am proud of the positive relationship I } \\
\text { have with my team. }\end{array}$ & .676 & & & & \\
\hline \multicolumn{7}{|c|}{ Factor 6 Informational Justice } \\
\hline 39 & $\begin{array}{l}\text { Departments in my organisation are } \\
\text { encouraged to build supportive } \\
\text { relationships with one another. }\end{array}$ & .731 & \multirow{7}{*}{4.016} & \multirow{7}{*}{6.179} & \multirow{7}{*}{50.99} & \multirow{7}{*}{0.862} \\
\hline 40 & $\begin{array}{l}\text { In my organisation, we report accurate } \\
\text { information in our records and files. }\end{array}$ & .678 & & & & \\
\hline 41 & $\begin{array}{l}\text { In our organisation we communicate } \\
\text { information in an honest manner to all } \\
\text { employees. }\end{array}$ & .673 & & & & \\
\hline 42 & $\begin{array}{l}\text { In my organisation we share information } \\
\text { about our products and services to } \\
\text { clients/customers in an honest and } \\
\text { consistent manner. }\end{array}$ & .637 & & & & \\
\hline 43 & $\begin{array}{l}\text { In my team we encourage all members to } \\
\text { be truthful when reporting information to } \\
\text { each other. }\end{array}$ & .535 & & & & \\
\hline 44 & $\begin{array}{l}\text { My organisation encourages open and } \\
\text { honest communication to all our } \\
\text { stakeholders. }\end{array}$ & .509 & & & & \\
\hline 45 & $\begin{array}{l}\text { I have a moral obligation to act ethically } \\
\text { when serving my clients/customers. }\end{array}$ & .508 & & & & \\
\hline \multicolumn{7}{|c|}{ Factor 7 Procedural justice } \\
\hline 29 & $\begin{array}{l}\text { The organisation has a fair employment } \\
\text { equity policy. }\end{array}$ & .637 & \multirow{5}{*}{2.911} & \multirow{5}{*}{4.479} & \multirow{5}{*}{55.47} & \multirow{5}{*}{0.887} \\
\hline 30 & $\begin{array}{l}\text { My organisation ensures employees have } \\
\text { equal access to the employee wellness } \\
\text { programme. }\end{array}$ & .555 & & & & \\
\hline 31 & $\begin{array}{l}\text { My organisation applies the disciplinary } \\
\text { policy and procedures consistently to all } \\
\text { employees. }\end{array}$ & .535 & & & & \\
\hline 32 & $\begin{array}{l}\text { In our organisation, our salary packages } \\
\text { are fair for employees in similar jobs and } \\
\text { positions. }\end{array}$ & .529 & & & & \\
\hline 33 & $\begin{array}{l}\text { The policy on employee benefits is } \\
\text { applied consistently to all employees. }\end{array}$ & .506 & & & & \\
\hline \multicolumn{7}{|c|}{ Factor 8 Diversity management justice } \\
\hline 35 & $\begin{array}{l}\text { In my organisation employees are able to } \\
\text { work together irrespective of their race, } \\
\text { gender, sexual orientation, religion or } \\
\text { age. }\end{array}$ & .726 & \multirow{4}{*}{2.803} & \multirow{4}{*}{4.312} & \multirow{4}{*}{59.78} & \multirow{4}{*}{0.863} \\
\hline 36 & In my organisation we value diversity. & 601 & & & & \\
\hline 37 & $\begin{array}{l}\text { Teams in my organisation have honest } \\
\text { working relationships. }\end{array}$ & .586 & & & & \\
\hline 38 & $\begin{array}{l}\text { Our leaders interact consistently with all } \\
\text { employees in the organisation. }\end{array}$ & .513 & & & & \\
\hline
\end{tabular}


(Table 3 continued)

\begin{tabular}{|c|c|c|c|c|c|c|}
\hline \multicolumn{7}{|c|}{ Factor 9 Customer relations justice } \\
\hline 47 & $\begin{array}{l}\text { I have an ethical obligation to my } \\
\text { profession when dealing with } \\
\text { clients/customers. }\end{array}$ & .625 & \multirow{4}{*}{2.525} & \multirow{4}{*}{3.885} & \multirow{4}{*}{63.67} & \multirow{4}{*}{0.815} \\
\hline 48 & $\begin{array}{l}\text { In my organisation we deliver our } \\
\text { products and services in an honest and } \\
\text { fair manner to clients/customers. }\end{array}$ & .570 & & & & \\
\hline 49 & $\begin{array}{l}\text { Our clients/ customers see my } \\
\text { organisation as having high moral } \\
\text { standards. }\end{array}$ & .513 & & & & \\
\hline 50 & $\begin{array}{l}\text { In my organisation we are encouraged to } \\
\text { protect the rights of clients/customers. }\end{array}$ & .503 & & & & \\
\hline $\begin{array}{l}\text { Extra } \\
\text { Rotat } \\
\text { a.9 co }\end{array}$ & $\begin{array}{l}\text { method: Principal component analysis. } \\
\text { nethod: Varimax with Kaiser normalisation } \\
\text { nents extracted }\end{array}$ & & & & & \\
\hline
\end{tabular}

\section{DISCUSSION OF RESULTS}

The objective of this study was to investigate the factors that influence the perceptions of organisational justice among employees in a South African government department. Factor 1, which was identified as distributive justice, consisted of 12 items that accounted for $14.0 \%$ of the variance. Distributive justice refers to employee perceptions about the fairness of managerial decisions relative to the distribution of outcomes such as pay, promotions and other benefits (Colquit, 2001; Liljegren and Ekberg, 2009). Cohen-Charash and Spector (2001) have argued that due to its focus on outcomes, distributive justice is predicted to be related mainly to cognitive, affective, and behavioural reactions to particular outcomes. Hence when a particular outcome is perceived to be unfair, it should affect the employee's emotions (e.g. lead to feelings of anger), cognitions (e.g. cognitively distort inputs and outcomes of oneself or other employees), and ultimately their behaviour (e.g. performance or withdrawal).

Factor 2, identified as ethical leadership and management, consisted of eleven items that accounted for $10.4 \%$ of the variance. According to Cropanzano et al. (2007), organisational justice is a personal evaluation about the ethical and moral standing of the organisation's leadership and managerial conduct. Ethical leadership and management implies that the leader and manager possess and promote justice values such as honesty, integrity, openness, compassion, humanity, equality, trust, recognition and empowerment (Werner, 2005). Ethics are important in a leader and manager's role because they serve as standards of right and wrong, which influence their behaviour. Hence organisations are not unethical or ethical but its people are. This implies that to create justice in the organisation, the leadership and management need to pursue integrity and ethical conduct (Cropanzano et al., 2007).

Factor 3, identified as service delivery and innovation, consisted of six items that accounted for $7.2 \%$ of the variance. It highlights the responsibility of employers and employees in ensuring that they create a just and fair image of the organisation with regard to the development and delivery of services or products. Goldstein, Johnston, Duffy and Rao (2002) have argued that regardless of how the service organisation defines their service and how customers or clients perceive the service, a delivered service should function seamlessly in order for customers to perceive it correctly (fair and just). In other words, service delivery innovation is a critical factor in understanding organisational justice.

Factor 4, identified as strategic direction justice, consisted of five items that accounted for $6.5 \%$ of the variance. Strategic direction is described and defined as the underlying purpose of the organisation, based on its vision and mission, business goals and objectives, operational plans as well as its organisational values (Werner, 2005; Mullins \& Christy, 2013). Creating a justice-oriented strategic direction for the organisation is one of the ways in which the organisation is able to indicate its concern for fair development and ethical execution of its purpose. Fair development of the strategic direction focuses on consultation with the relevant stakeholders during the decision-making process. Cropazano et al. (2007) have indicated that justice creates the trust and commitment that build voluntary cooperation in strategy execution. 
Factor 5, identified as interactional justice, consisted of five items that also accounted for $6.5 \%$ of the variance. Interactional justice is focused on the interpersonal side of organisational practices, specifically, the interpersonal treatment by management to employees (Cohen-Charash and Spector, 2001). This concept was derived from employee reports of unfair treatment, which frequently focused on interpersonal rather than structural factors (Greenberg, 1990). It reflects the quality of interpersonal treatment an employee receives in the organisation during the enactment of organisational procedures (Moorman, 1991; McFarlin and Sweeney, 1992).

Factor 6, identified as informational justice, consisted of seven items that accounted for $6.1 \%$ of the variance. Informational justice therefore refers to whether one is truthful and provides adequate justifications to all the recipients (Cropanzano et al., 2007). According to Colquitt et al. (2001), informational justice is able to assist employees to evaluate the structural aspects of the process in organisations. It is concerned with the fairness of the interpersonal communication. This implies that employees are likely to perceive justice in the organisation when they are provided with adequate and truthful information during the decision-making processes in the organisation.

Factor 7, identified as procedural justice, consisted of five items that accounted for $4.4 \%$ of the variance. Procedural justice refers to the fairness of the process by which outcomes are determined and it is considered to exist when procedures embody certain types of normatively accepted principles (Cohen-Charash and Spector, 2001; DeConick, 2010). This implies that justice perceptions also depend on the organisation's adherence to procedural justice rules. Van der Bank (2010) has indicated that procedurally fair treatment could result in positive organisational outcomes, such as organisational commitment, interpersonal trust, job satisfaction, organisational citizenship behaviour and job performance.

Factor 8 , identified as diversity management justice, consisted of four items that accounted for $4.3 \%$ of the variance. Broadly defined, the term diversity management refers to the systematic and planned commitment by organisations to recruit, retain, reward, and promote a heterogeneous mix of employees (Invancevich and Gilbert, 2000). Diversity management stresses the necessity of recognising cultural differences between groups of employees, and making practical allowances for such differences in organisational policies (Wrench, 2005; Gilbert et al., 1999). An organisation that is devoted to diversity management is able to give the impression that the company has established systems which fairly evaluate, promote, and compensate its employees based upon performance and ability rather than on criteria such as gender, nationality, or age (Magoshi and Chang, 2009). Therefore, employees' perception of organisational justice can be a major effect created by diversity strategies.

Factor 9, identified as customer relations justice, consisted of four items that accounted for $3.8 \%$ of the variance. Customer relation is basically concerned with maintaining positive relationships with customers, increasing customer loyalty, and expanding customer lifetime value (King and Burgess, 2008). Hence an understanding of the needs of customers and offering value-added services are recognised as factors that determine the success or failure of companies. According to Bose (2002), from an operations perspective, customer relations encompass an integration of technologies and business processes that are adopted to satisfy the needs of a customer during any given interaction. Therefore, customer relations practices in the organisation that are fair and just can help organisations manage customer interactions more effectively.

The findings of this study, that there are nine organisational justice factors, have extended previous research on organisational justice, which has been based on three, overlapping, models. Firstly, there is the two-factor model (distributive and procedural justice) in which interpersonal justice is subsumed under procedural justice (McFarlin and Sweeney, 1992; Roch and Shanock, 2006). Secondly, there is the three-factor model focusing on the distributive, procedural and interaction justice (Liljegren and Ekberg, 2009; DeConick, 2010). Thirdly, there is the four-factor model focusing on distributive, procedural, interpersonal and informational justice (Colquitt, 2001).

\section{CONCLUSIONS}

The purpose of this study was to investigate the factors that influence the perceptions of organisational justice among government department employees. This aim was achieved using the exploratory factor analysis to identify the nine factors, namely strategic direction, distributive, procedural, interactional, informational, service delivery and innovation, diversity management, customer relations, ethical leadership and management. Among 
these factors, it emerged that the employees of the selected government department perceived that there was more justice in terms of interactional justice and less justice in terms of distributive justice.

In terms of the limitations, this study was conducted in one province rather than in all nine provinces where the department has offices. This geographic limitation implies that the study was restricted to a single geographic context. The second limitation is based on the fact that a cross-sectional survey was used rather than a longitudinal survey, which might yield different results. Future research could focus on longitudinal studies to explain organisational justice. In addition, future studies could investigate perceptions of organisational justice across the different government departments in all provinces.

The findings of this study have a number of implications for management in organisations. Managers and employee relations practitioners in government departments are constantly involved in the development and implementation of organisational polices and processes that are supposed to reflect just and fair practices in their department. They could make use of the identified nine factors to initiate and implement relevant interventions to enhance organisational justice. Lastly, this study can help organisations to develop pertinent, relevant and affordable training programmes on organisational justice that benefit all stakeholders in the organisation.

\section{AUTHOR INFORMATION}

Professor Ophillia M. Ledimo is the head of the Department of Industrial and Organisational Psychology at the University of South Africa (UNISA). She has published numerous accredited articles in refereed journal and proceedings. She is the section editor of the South African Journal of Industrial Psychology. She has presented papers at national and international conferences and is a registered Industrial Psychologist. She holds a DLit et Phil from the University of South Africa. Prof Ophillia Ledimo, Ph.D., Department of Industrial and Organisational Psychology, University of South Africa, P.O. Box 392, Pretoria, South Africa, 0003. Phone number: +27 12429 8219. Email:manetom@unisa.ac.za

\section{REFERENCES}

Adams, J. S. (1965). Inequity in social exchange. In L. Berkowitz (Ed.), Advances in experimental social psychology (Vol. 2, pp. 267-299). New York: Academic Press.

Avikaran, N. K. (1994). Developing an instrument to measure service quality in branch banking. International Journal of Bank Marketing, 12 (6), 10 - 18.

Bose, R. (2002). Customer relationship management: Key components for IT success. Industrial Management and Data Systems, $102(2), 89-97$.

Bowen, D. E., Gilliland, S. W., \& Folger, R. (1999). HRM and service justice: How being just with employees spills over to customers. Organizational Dynamics, 27, 7-23.

Brown, T. A. (2006). Confirmatory factor analysis for applied research. New York: Guilford Press.

Chalmet, R. (2006). Methodology for customer relationship management. The Journal of Systems and Software, 79, 10151024

Chen, J. S, Tsou, H. T., \& Huang, A.Y. (2009). Service delivery innovation antecedents and impact on firm performance. Journal of Service Research, 12 (1), 36-55.

Cohen-Charash, Y., \& Spector, P. E. (2001). The role of justice in organizations: a meta-analysis. Organizational Behavior and Human Decision Processes, 86 (2), 278-321.

Colquitt, J. A. (2001). On the dimensionality of organizational justice: a construct validation of a measure. Journal of Applied Psychology, 86, 386-400.

Cropanzano, R., Rupp, D. E., Mohler, C., J \& Schminke, M. (2001). Three roads to organizational justice. Research in Personnel and Human Resources Management, 20, 1-113.

Cropanzano, R; Bowen, D. E., \& Gilliland, W. (2007). The management of organizational justice. Academy of Management Perspectives, November, $34-47$.

Cropanzano, R., Prehar, C. A., \& Chen, P. Y. (2002). Using social exchange theory to distinguish procedural from interactional justice. Group and Organizational Management, 27, 324-351.

DeConick, J.B. (2010). The effect of organizational justice, perceived organizational support, and perceived supervisor support on marketing employees' level of trust. Journal of Business Research, 63, 1349-1355. 
Esterhuizen, W. \& Martins, N. (2008). Organisational justice and employee responses to employment equity. South African Journal of Labour Relations, 32 (2), $65-85$.

Gaudet, M. C., Tremblay, M., \& Doucet, O. (2014). Exploring the black box of the contingent reward leadershipperformance relationship: The role of the perceived justice and emotional exhaustion. European Journal of Work and Organizational Psychology, 23 (6), 897 -914.

Gilbert, J. A., Stead, B. A., \& Ivancevich, J. M. (1999). Diversity management: a new organizational paradigm. Journal of Business Ethics, 21, 61-76.

Goldstein, S. M., Johnston, R., Duffy, J., \& Rao, J. (2002). The service concept: the missing link in service design research? Journal of Operations Management, 20, 121-134.

Greenberg, J. (1987). Reactions to procedural injustice in payment distributions: Do the means justify the ends? Journal of Applied Psychology, 72, 55-61.

Greenberg, J. (1990). Organizational justice: yesterday, today, and tomorrow. Journal of Management, 16, $399-432$.

Greenberg, J. (2001). Studying organizational justice cross-culturally: Fundamental challenges. International Journal of Conflict Management, 12 (4), 365 - 367.

Hair, J. F., Black, B., Babin, B., Anderson, R. E., Tatham, R. L., \& Black, W. C. (2010). Multivariate data analysis: A global perspective. New York: Pearson Education.

Injazz, D., \& Karen, P. 2004. Understanding customer relationship management (CRM). People, process and technology. Available: http://www.emeraldinsight.com/1463-7154.htm (accessed on 20 September 2014).

Ivancevich, J. M. \& Gilbert, J. A. (2000). Diversity management time for a new approach. Public Personnel Management, 29 (1). 75-91.

Johnson, C. E. (2009). Meeting the ethical challenges of leadership: Casting light or shadow. London: Sage.

Johnson, R. A., \& Wichern, D. W. (2002). Applied multivariate statistical analysis. Upper Saddle River, NJ: Prentice Hall.

Kahn, J. (2006). Factor analysis in counseling psychology research, training, and practice: principles, advances and applications. The Counseling Psychologist, 34-684.

Kim, W. C. \& Mauborgne, R. A. (1993). Procedural justice, attitudes, and subsidiary top management compliance with multinationals' corporate strategic decisions. Academy of Management Journal, 36, 502-526.

King, S. F., \& Burgess, T. F. (2008). Understanding success and failure in customer relationship management. Industrial Marketing Management, 37, 421-431.

Liljegren, M., \& Ekberg, K. (2009). The associations between perceived distributive, procedural, and interactional organizational justice, self-rated health and burnout. Work, 33, 43-51.

Lovelock, C., \& Evert, G. (2004). Whither services marketing? In search of a new paradigm and fresh perspectives. Journal of Service Research, 7 (1), 9-20.

Magoshi, E., \& Chang, E. (2009). Diversity management and the effects on employees' organizational commitment: Evidence from Japan and Korea. Journal of World Business, 44, 31-40.

McFarlin, D., \& Sweeney, P. (1992). Distributive and procedural justice as predictors of satisfaction with personal and organizational outcomes. Academy of Management Journal, 35(3), 626-637.

Moorman, R. H. (1991). Relationship between organizational justice and organizational citizenship behaviors: Do fairness perceptions influence employee citizenship? Journal of Applied Psychology, 76, 845-55.

Pilvinyte, M. (2013). Perceptions of organisational justice, restorative organisational justice, and their relatedness to perceptions of organisational attractiveness. Unpublished Masters Dissertation. University of Witwatersrand.

Roch, S. G., \& Shanock, L. R. (2006). Organizational justice in an exchange framework: clarifying organizational justice distinctions. Journal of Management, 32(2), 299-322.

Shibaoka, M., Takade, M., Watanabe, M., Kojima, R., Kakinuma, M., Tanaka, K., \& Kawakami, N. (2010). The development and validation of the Japanese version of the organisational justice scale. Industrial health, 48, 66 73.

Tabachnik, B. G., \& Fidell, L. S. (2001). Using multivariate statistics. Boston: Allyn \& Bacon.

TerreBlanche, M., Durrheim, K., \& Painter, D. (2006). Research in practice: applied methods for the social sciences. Cape Town: University of Cape Town Press.

SPSS Inc. (2006). SPSS version 14.0 for the Microsoft Windows platform. Chicago: SPSS Inc.

Van der Bank, L., Engelbrecht, A., \& Stumpher, J. (2010). Perceived fairness of disciplinary procedures in the public sector: an exploratory study. South African Journal of Human Resource Management, 6 (2), 1-8.

Welman, C., Kruger, F., \& Mitchell, B. (2009). Research methodology. Cape Town: Oxford University Press.

Werner, A. (2005). Organizational behaviour: A contemporary South African perspective. Pretoria: Van Schaik.

Wrech, J. (2005). Diversity management can be bad for you. Race \& Class, 46 (3), 73-84. 